\title{
Occurrence of Pseudovitamin $B_{12}$ and Its Possible Function as the Cofactor of Cobalamin-Dependent Methionine Synthase in a Cyanobacterium Synechocystis sp. PCC6803
}

\author{
Yuri TANIOKA ${ }^{1}$, Yukinori YABUTA ${ }^{2}$, Ryoichi YAMAJi ${ }^{3}$, Shigeru SHIGEOKA ${ }^{4}$, \\ Yoshihisa NAKANO ${ }^{5}$, Fumio WATANABE ${ }^{2}$ and Hiroshi INUI ${ }^{3}$ \\ ${ }^{1}$ Department of Nutrition, Junior College of Tokyo University of Agriculture, \\ Setagaya-ku, Tokyo 156-8502, Japan \\ ${ }^{2}$ School of Agricultural, Biological, and Environmental Sciences, Faculty of Agriculture, Tottori University, \\ 4-101 Koyama-Minami, Tottori 680-8553, Japan \\ ${ }^{3}$ Graduate School of Life and Environmental Sciences, Osaka Prefecture University, Gakuen-cho, \\ Naka-ku, Sakai, Osaka 599-8570, Japan \\ ${ }^{4}$ Department of Advanced Bioscience, Faculty of Agriculture, Kinki University, Nakamachi, \\ Nara 631-8505, Japan \\ ${ }^{5}$ Center for Research and Development Bioresources, Organization for University-Industry-Government \\ Cooperation, Osaka Prefecture University, Gakuen-cho, Naka-ku, Sakai, Osaka 599-8570, Japan
}

(Received July 7, 2009)

\begin{abstract}
Summary To clarify the physiological function of pseudovitamin $\mathrm{B}_{12}$ in cyanobacteria, we determined pseudovitamin $\mathrm{B}_{12}$ contents and cobalamin-dependent methionine synthase activity in Synechocystis sp. PCC6803 grown under $\mathrm{CoSO}_{4}$-sufficient and -limited conditions. Pseudovitamin $\mathrm{B}_{12}$ and cobalamin-dependent methionine synthase activity $(0.8 \mathrm{nmol} / \mathrm{min} /$ $\mathrm{mg}$ protein) were found in a homogenate of the Synechocystis cells grown for $10 \mathrm{~d}$ in the $\mathrm{CoSO}_{4}$-sufficient medium. The cellular pseudovitamin $\mathrm{B}_{12}$ contents increased significantly at the early logarithmic growth phase and thereafter decreased rapidly at the stationary phase; a similar fluctuation pattern was shown in the cobalamin-dependent methionine synthase activity. Although the $\mathrm{CoSO}_{4}$-limited conditions did not reduce the cell growth, pseudovitamin $B_{12}$ contents and methionine synthase activity decreased significantly in the limited cells relative to the sufficient cells. These results indicate that the cyanobacterium Synechocystis sp. PCC6803 can synthesize pseudovitamin $\mathrm{B}_{12}$ de novo and utilize it as the cofactor for cobalamin-dependent methionine synthase.
\end{abstract}

Key Words pseudovitamin $\mathrm{B}_{12}$, methionine synthase, cyanobacteria, Synechocystis sp. PCC6803

Vitamin $\mathrm{B}_{12}$ or cyanocobalamin $\left(\mathrm{B}_{12}\right)$ has a corrin ring in which the central cobalt atom is coordinated by tetra-pyrroles. Two axial (upper and lower) ligands also coordinate the cobalt atom. The lower ligand of $\mathrm{B}_{12}$ molecule contains a cobalt-coordinated nucleotide with 5,6-dimethylbenzimidazole as a base. The upper ligand consists of either $5^{\prime}$-deoxyadenosine (adenosylcobalamin) or a methyl group (methylcobalamin), which functions as the cofactor for methylmalonyl-CoA mutase (MCM, EC 5.4.99.2) and methionine synthase (MS, EC 2.1.1.13), respectively, in mammals (1).

Certain bacteria can synthesize $\mathrm{B}_{12}$ and/or other $\mathrm{B}_{12}$ related compounds with a variety of alternative bases (adenine, pseudovitamin $\mathrm{B}_{12} ; 2$-methyladenine, Factor $\mathrm{A}$; and so on) in the lower ligand $(2,3)$. We have previously reported that edible cyanobacteria (Spirulina platensis, Aphanothece sacrum, Aphanizomenon fros-aquae, Nostoc commune, and Nostoc flagelliforme) contain a substantial amount of pseudovitamin $\mathrm{B}_{12}$ (4-8). However,

E-mail: y3taniok@nodai.ac.jp there is little information available on whether these cyanobacteria have the ability to synthesize pseudovita$\min \mathrm{B}_{12}$ de novo, and whether pseudovitamin $\mathrm{B}_{12}$ functions as a cofactor for certain cobalamin-dependent enzymes. Although most of these edible cyanobacteria are difficult to use as experimental organisms because of their low growth rates and little biochemical and genomic information, Synechocystis sp. PCC6803 has been studied extensively as a model of cyanobacterial species in many scientific fields (biochemistry, molecular biology, and so on).

In this paper, we describe the occurrence of pseudovitamin B 12 in Synechocystis sp. PCC6803, and the effects of the addition or depletion of cobalt ion as a constituent of pseudovitamin $B_{12}$ on its cell growth, pseudovitamin $B_{12}$ contents, and cobalamin-dependent MS activity. We also discuss the physiological function of pseudovitamin $\mathrm{B}_{12}$ in this organism.

\section{Materials and Methods}

Materials. $\mathrm{B}_{12}$ and methylcobalamin $\left(\mathrm{CH}_{3}-\mathrm{B}_{12}\right)$ were 
obtained from Sigma (St. Louis, USA). Pseudovitamin $\mathrm{B}_{12}$ purified and identified previously from Aphanizomenon flos-aquae (6) was used as an authentic preparation. A $\mathrm{B}_{12}$ assay medium for Lactobacillus delbrueckii was obtained from Nissui (Tokyo, Japan). Silica gel 60 thinlayer chromatography (TLC) aluminium sheets were obtained from Merck (Darmstadt, Germany).

Organisms and culture conditions. Synechocystis sp. PCC6803 was grown in Allen medium (9) (5 L) containing $0.18 \mathrm{mM} \mathrm{CoSO}$, aseptically bubbled with air $\left(3 \mathrm{~mL} / \mathrm{min}\right.$ ) at $25^{\circ} \mathrm{C}$, and illuminated at $240 \mu \mathrm{E} / \mathrm{m}^{2} / \mathrm{s}$ for $10 \mathrm{~d}$. The cells grown under the conditions were used as the $\mathrm{CoSO}_{4}$-sufficient cells. The $\mathrm{CoSO}_{4}$-sufficient cells were inoculated into Allen medium $(5 \mathrm{~L})$ without $\mathrm{CoSO}_{4}$, cultured for $10 \mathrm{~d}$, and used as the $\mathrm{CoSO}_{4}$-limited cells. The $\mathrm{CoSO}_{4}$-limited cells were further inoculated into the medium ( $5 \mathrm{~L}$ ) without $\mathrm{CoSO}_{4}$, cultured for $10 \mathrm{~d}$, and used as the $\mathrm{CoSO}_{4}$-deficient cells. The cell growth was determined in each cell culture grown for the indicated time courses by measuring absorbance at $750 \mathrm{~nm}$.

Extraction and assay of pseudovitamin $B_{12}$. The cell culture grown for the indicated time courses was centrifuged at $5,000 \times g$ for $10 \mathrm{~min}$ to collect the cells. The precipitated cells were washed twice with distilled water, and then stored at $-80^{\circ} \mathrm{C}$ until use. The stored cells (about $2 \mathrm{~g}$ wet weight) were disrupted with sonic treatment $(6 \mathrm{kHz}, 60 \mathrm{~s}$, three times), and boiled for $30 \mathrm{~min}$ at $57 \mathrm{mmol} / \mathrm{L}$ acetate buffer $(\mathrm{pH} 4.5)$ containing $0.05 \%(\mathrm{w} / \mathrm{v}) \mathrm{KCN}$. The extraction procedure was done in a Dalton (Tokyo, Japan) draft chamber. Pseudovitamin $\mathrm{B}_{12}$ was assayed with $\mathrm{B}_{12}$ as a standard by a bioassay method (10) using Lactobacillus delbrueckii subsp. lactis ATCC7830.

Bioautography with $B_{12}$-dependent Escherichia coli 215. Pseudovitamin $B_{12}$ found in the above cell extract was separated with silica gel 60 TLC, and visualized with $\mathrm{B}_{12}$-dependent Escherichia coli 215 bioautography as described previously (8).

Enzyme assay. Synechocystis cells $(0.1 \mathrm{~g})$ were suspended in $0.5 \mathrm{~mL}$ of $10 \mathrm{mmol} / \mathrm{L}$ potassium phosphate buffer ( $\mathrm{pH} 7.0)$, containing 10\% (w/v) sucrose, disrupted by a bead beater (Biospec Products, USA) (15 s strokes with $45 \mathrm{~s}$ intervals, 8 times), and centrifuged at $5,000 \times g$ for $20 \mathrm{~min}$ at $4^{\circ} \mathrm{C}$. The supernatant was used as the crude extract.

Methionine synthase was assayed at $37^{\circ} \mathrm{C}$ under anaerobic conditions according to Banerjee et al. (11). The reaction mixture $(0.5 \mathrm{~mL})$ contained $100 \mathrm{mmol} / \mathrm{L}$ potassium phosphate buffer ( $\mathrm{pH} 7.2), 500 \mu \mathrm{mol} / \mathrm{L} \mathrm{DL}-$ homocysteine, $19 \mu \mathrm{mol} / \mathrm{L} S$-adenosyl-L-methionine, 6 $\mathrm{mmol} / \mathrm{L}$ titanium citrate, $250 \mu \mathrm{mol} / \mathrm{L}(6 \mathrm{R}, 6 \mathrm{~S})-5-\mathrm{CH}_{3}-$ $\mathrm{H}_{4}$-folate, and the crude enzyme. The reaction was initiated with $\mathrm{CH}_{3}-\mathrm{H}_{4}$-folate, incubated for $30 \mathrm{~min}$ at $37^{\circ} \mathrm{C}$, and terminated by heating at $98^{\circ} \mathrm{C}$ for $2 \mathrm{~min}$. The $\mathrm{H}_{4}$ folate formed by the enzyme reaction was assayed with HPLC as described in the cited reference (12). Apo-MS activity was calculated by subtracting the holo-MS activity (in the absence of $\mathrm{CH}_{3}-\mathrm{B}_{12}$ ) from the total MS activity (in the presence of $50 \mu \mathrm{mol} / \mathrm{L} \mathrm{CH}_{3}-\mathrm{B}_{12}$ ).

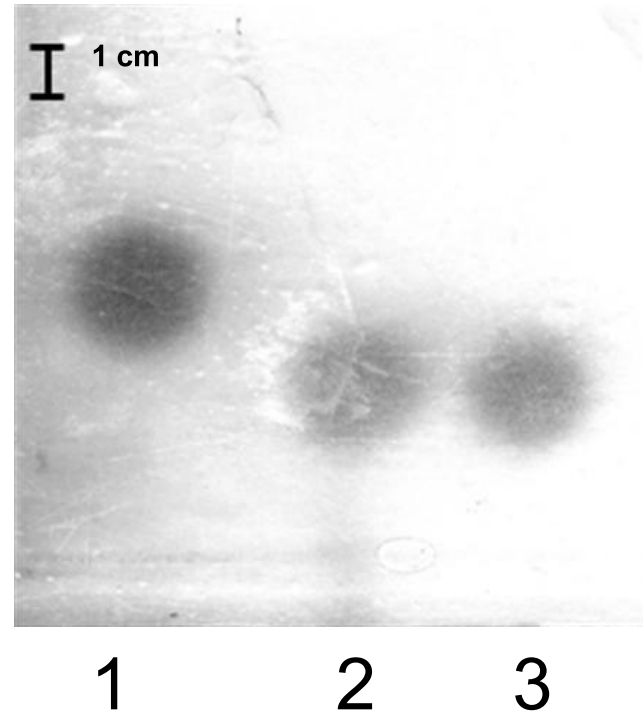

Fig. 1. Bioautogram of pseudovitamin $B_{12}$ found in the Synechocystis cells. Corrinoid compounds were extracted from the Synechocystis cells grown for $10 \mathrm{~d}$ under the $\mathrm{CoSO}_{4}$-sufficient conditions, separated with a silica gel $60 \mathrm{TLC}$, and visualized with $\mathrm{B}_{12}$-dependent $E$. coli 215. 1: authentic $\mathrm{B}_{12} ; 2$ : authentic pseudovitamin $\mathrm{B}_{12} ; 3$ : Synechocystis cell extract. The data are a typical bioautogram from three independent experiments.

Protein assay. Proteins were assayed with ovalbumin as a standard by the method of Bradford (13).

\section{Results and Discussion}

Identification of pseudovitamin $B_{12}$ found in the Synechocystis cells

To clarify whether the Synechocystis cells grown in the $\mathrm{CoSO}_{4}$-sufficient medium contain considerable amounts of pseudovitamin $\mathrm{B}_{12}$, corrinoid compounds were extracted, separated with silica gel 60 TLC, and then visualized with $\mathrm{B}_{12}$-dependent $E$. coli 215 bioautography (Fig. 1). The $\mathrm{B}_{12}$-active compound of the Synechocystis cell homogenate was found as only one spot, whose $R f$ value was identical to that of authentic pseudovitamin $\mathrm{B}_{12}$. The genome database for cyanobacteria (CyanoBase; http://www.kazusa.or.jp) indicates that the Synechocystis cells contain the gene homologs of the enzymes involved in the $\mathrm{B}_{12}$ biosynthesis. These results suggest that the Synechocystis cells have the ability to synthesize pseudovitamin $\mathrm{B}_{12}$ de novo.

Occurrence of the cobalamin-dependent MS in the Synechocystis cells

The CyanoBase indicates that Synechocystis sp. PCC6803 contains a gene similar to metH (slr0212) encoding cobalamin-dependent MS, but not to metE encoding cobalamin-independent MS. It did not contain any genes related with other cobalamin-dependent enzymes (MCM, ribonucleotide reductase, diol dehydratase, and so on), either.

We assayed the cobalamin-dependent MS activity in the cell homogenates of the Synechocystis cells grown in the $\mathrm{CoSO}_{4}$-sufficient medium and some mammalian cells. The Synechocystis cells showed considerably 

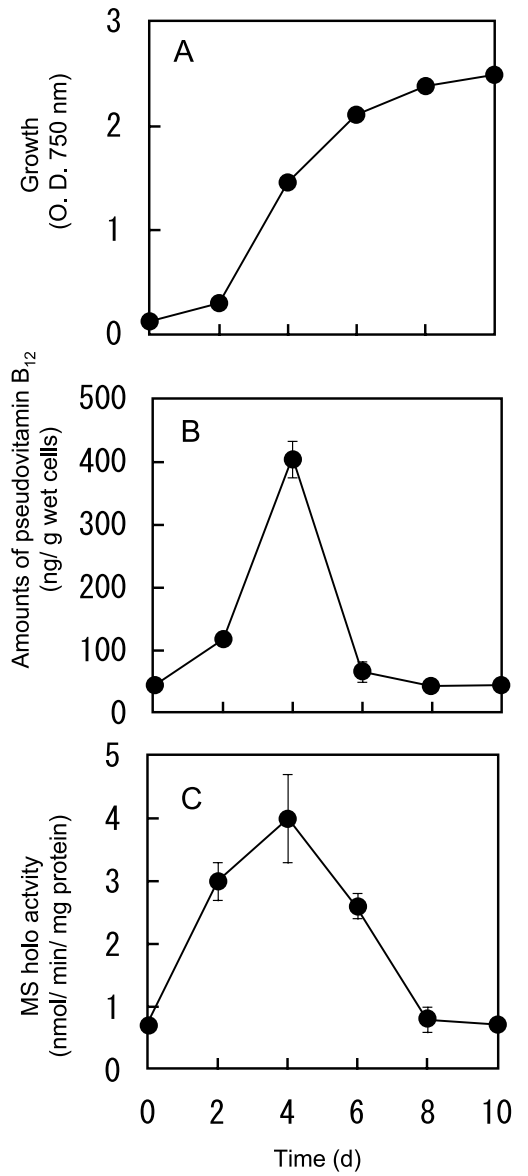

Fig. 2. Changes in pseudovitamin $\mathrm{B}_{12}$ contents and MS activity during the growth of Synechocystis cells under the $\mathrm{CoSO}_{4}$-sufficient conditions. Synechocystis cells were grown in a medium supplemented with $\mathrm{CoSO}_{4}$ at $0.18 \mathrm{mmol} / \mathrm{L}$ for $10 \mathrm{~d}$. Cell density in the culture medium (A), pseudovitamin $\mathrm{B}_{12}$ content (B), and MS (holo-enzyme) activity $(\mathrm{C})$ were assayed at the indicated time courses by the methods described in the text. The data represent means \pm SD from three independent experiments.

higher MS activity $(0.80 \mathrm{nmol} / \mathrm{min} / \mathrm{mg}$ protein $)$ than the Cos- 7 monkey kidney cells $(0.67 \mathrm{nmol} / \mathrm{min} / \mathrm{mg}$ protein) and rat liver $(0.14 \mathrm{nmol} / \mathrm{min} / \mathrm{mg}$ protein $)$ did. These results suggest that pseudovitamin $\mathrm{B}_{12}$ can function as the cofactor of the cobalamin-dependent MS because it is the only corrinoid compound found in the Synechocystis cells.

Changes in pseudovitamin $B_{12}$ contents and MS activity during growth of the Synechocystis cells under the $\mathrm{CoSO}_{4}$ sufficient conditions

The cellular pseudovitamin $\mathrm{B}_{12}$ contents increased significantly at the early logarithmic growth phase and thereafter decreased rapidly at the stationary phase; a similar fluctuation pattern was shown in the cobalamin-dependent MS activity (Fig. 2). These results suggest that the MS actively functions in the DNA synthesis at the early logarithmic growth phase.

Effects of the depletion of $\mathrm{CoSO}_{4}$ as a constituent of pseudovitamin $B_{12}$ on the cell growth, pseudovitamin $B_{12}$ contents and MS activity in the Synechocystis cells

To determine whether the depletion of $\mathrm{CoSO}_{4}$ can
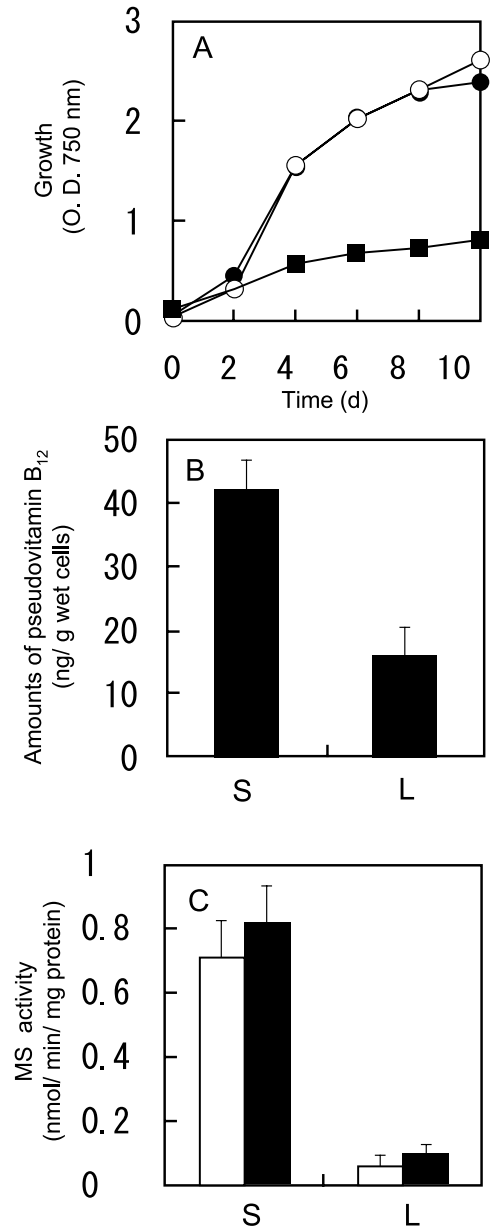

Fig. 3. Effects of the depletion of $\mathrm{CoSO}_{4}$ on the growth, pseudovitamin $\mathrm{B}_{12}$ contents, and MS activity in Synechocystis cells. A: Synechocystis cells were grown under the $\mathrm{CoSO}_{4}$-sufficient $(\bullet)$, -limited $(\mathrm{O})$ or -deficient $(\boldsymbol{\square})$ conditions. B: Pseudovitamin $\mathrm{B}_{12}$ contents were extracted from the cell grown for $10 \mathrm{~d}$ under the $\mathrm{CoSO}_{4}$ sufficient (S) and -limited (L) conditions and assayed. C: MS activity was determined in the absence $(\square)$ or presence (-) of $\mathrm{CH}_{3}-\mathrm{B}_{12}$ using the homogenates of Synechocystis cells grown under the $\mathrm{CoSO}_{4}$-sufficient (S) and -limited (L) conditions. The data represent means \pm SD from four independent experiments.

affect pseudovitamin $\mathrm{B}_{12}$ contents, MS activity, and cell growth, Synechocystis cells were grown under the $\mathrm{CoSO}_{4}$-limited and -deficient conditions. Hardly any Synechocystis cells were grown under the $\mathrm{CoSO}_{4}$-deficient conditions (Fig. 3A). These results suggest that Synechocystis sp. PCC6803 absolutely requires the cobalt ion as a constituent of pseudovitamin $\mathrm{B}_{12}$ for cell growth. Although the $\mathrm{CoSO}_{4}$-limited conditions did not reduce the cell growth, pseudovitamin $\mathrm{B}_{12}$ contents decreased significantly in the limited cells relative to the $\mathrm{CoSO}_{4}$-sufficient cells (Fig. 3B). The MS activity of the $\mathrm{CoSO}_{4}$-limited cells was also decreased as low as about $10 \%$ of the activity of the $\mathrm{CoSO}_{4}$-sufficient cells.

To evaluate whether the $\mathrm{CoSO}_{4}$-limited cells contain the apo-enzyme of the MS, the MS activity was determined after being converted from the apo-enzyme to the holo-enzyme by pre-incubation with $\mathrm{CH}_{3}-\mathrm{B}_{12}$ (Fig. 
3C). There was no change in the MS activity of the $\mathrm{CoSO}_{4}$-sufficient or -limited cells in the presence or absence of added $\mathrm{CH}_{3}-\mathrm{B}_{12}$, suggesting that MS predominantly exists as the holo-enzyme in both $\mathrm{CoSO}_{4}$-sufficient and -limited cells. These results indicate that the decrease in the MS activity of the $\mathrm{CoSO}_{4}$-limited cells may be due to a decrease in the stability of the enzyme protein because the pseudovitamin $\mathrm{B}_{12}$ contents were significantly low in the limited cells. Yamada et al. (14, 15) have demonstrated that MS activity became extremely low in $\mathrm{B}_{12}$-deficient rats and that the rat apoenzyme is very unstable and stabilized by forming a complex with $\mathrm{CH}_{3}-\mathrm{B}_{12}$.

These results presented here indicated that Synechocystis sp. PCC6803 (probably the edible cyanobactria) has the ability to synthesize pseudovitamin $\mathrm{B}_{12}$ de novo and then to utilize the compound as the cofactor for cobalamin-dependent MS.

\section{REFERENCES}

1) Watanabe F. 2007. Vitamin $B_{12}$ sources and bioavailability. Exp Biol Med 232: 1266-1274.

2) Santos F, Vera JL, Lamosa P, de Valdez F, Willem M de Vos, Santos H, Sesma F, Hugenholtz J. 2007. Pseudovitamin $\mathrm{B}_{12}$ is the corrinoid produced by Lactobacillus reuteri CRL 1098 under anaerobic conditions. FEBS Lett 581: 4865-4870.

3) Hoffman B, Oberhuber M, Sttupperich E, Bothe H, Bucked W, Konrat R, Krautler B. 2000. Native corrinoids from Clostridium cochlearium are adeninylcobamides: spectroscopic analysis and identification of pseudovitamin $\mathrm{B}_{12}$ and factor A. J Bacteriol 182: 47734782.

4) Watanabe F, Katsura H, Takenaka S, Fujita T, Abe K, Tamura Y, Nakatsuka T, Nakano Y. 1999. Pseudovitamin $\mathrm{B}_{12}$ is the predominant cobamide of an algal health food, Spirulina tablets. J Agric Food Chem 47: 47364741.

5) Watanabe F, Miyamoto E, Fujita T, Tanioka Y, Nakano Y. 2006. Characterization of a corrinoid compound in the edible (blue-green) alga, Suizenji-nori. Biosci Biotechnol Biochem 70: 3066-3068.

6) Miyamoto E, Tanioka Y, Nakao T, Balra F, Inui H, Fujita T, Watanabe F, Nakano Y. 2006. Purification and char- acterization of a corrinoid-compound in an edible cyanobacterium Aphanizomenon flos-aquae as a nutritional supplementary food. J Agric Food Chem 54: 9604-9607.

7) Watanabe F, Tanioka Y, Miyamoto E, Fujita T, Takenaka H, Nakano Y. 2007. Purification characterization of a corrinoid compounds from the dried powder of an edible cyanobacterium, Nostoc commune (Ishikurage). J Nutr Sci Vitaminol 53: 183-186.

8) Tanioka Y, Yabuta Y, Miyamoto E, Inui H, Watanabe F. 2008. Analysis of vitamin $\mathrm{B}_{12}$ in food by silica gel 60 TLC and bioautography with vitamin $\mathrm{B}_{12}$-dependent Escherichia coli 215. J Liq Chromatogr Relate Technol 31: 1977-1985.

9) Allen MM. 1968. Simple conditions for the growth of unicellular blue-green algae on plants. J Phycol 4: 1-4.

10) Watanabe F, Miyamoto E, Nakano Y. 2001. Inactive corrinoid-compound significantly decreases in Spirulina platensis grown in a cobalt-deficient medium. J Agric Food Chem 49: 5685-5688.

11) Banerjee R, Chen Z, Gulati S. 1997. Methionine synthase from pig liver. Methods Enzymol 281: 189-196.

12) Huang L, Zhang J, Hayakawa T. 2001. Assays of methylenetetrahydrofolate reductase and methionine synthase activities by monitoring 5-methyltetrahydrofolate and tetrahydrofolate using high-performance liquid chromatography with fluorescence detection. Anal Biochem 299: 253-259.

13) Bradford MM. 1976. A rapid and sensitive method for the quantitation of microgram quantities of protein utilizing the principle of protein-dye binding. Anal Biochem 72: 248-254.

14) Yamada K, Yamada S, Tobimatsu T, Toraya T. 1990. Heterologous high level expression, purification, and enzymological properties of recombinant rat cobalamin-dependent methionine synthase. J Biol Chem 274: 35571-35576.

15) Yamada K, Kawata T, Wada M, Isshiki T, Onoda J, Kawanishi T, Kunou A, Tadokoro T, Tobimatsu T, Maekawa A, Toraya T. 2000. Extremely low activity of methionine synthase in vitamin $\mathrm{B}_{12}$-deficient rats may be related to effects on coenzyme stabilization rather than to changes in coenzyme induction. J Nutr 130: 1894-1900. 